\title{
Codification of the Criminal Law
}

\author{
7. C. Smith*
}

In a paper delivered to the Statute Law Society in October, $1983^{1}$ I explained what the codification team was trying to do and how it was trying to do it. Since then, our report to the Law Commission has been published ${ }^{2}$ and a substantial number of comments on the proposals have been received. Some are favourable, some are critical. Today I propose to respond to some of the criticisms, not of matters of detail, but of the general principle of codification. I shall be expressing only my personal views which are not necessarily those of my colleagues, still less of the Law Commission.

It has been suggested that the supporters of codification believe in it for its own sake. I do not. Throughout my career I have always taught the law of contract as well as criminal law; but I never had any enthusiasm for the Commission's proposal, now abandoned, to codify the law of contract. I did not support it because I could see no practical advantage in it. The law of contract appears to me to be a generally consistent, coherent and logical system. It has broad general principles which are readily applicable to a wide variety of situations and adaptable to changing circumstances. The criminal law is entirely different. It is incoherent and inconsistent. State almost any general principle and you find one or more leading cases which contradict it. It is littered with distinctions which have no basis in reason but are mere historical accidents. I am in favour of codification of the criminal law because I see no other way of reducing a chaotic system to order, of eliminating irrational distinctions and of making the law reasonably comprehensible, accessible and certain. These are all practical objects. Irrational distinctions mean injustice. A is treated differently from $B$ when there is no rational ground for treating him differently; and that is not justice.

\section{The Code and law reform}

The draft code is not a mere restatement of the present law. With the concurrence of the Law Commission, we incorporated a number of proposals for reform, in

* Professor of Law, University of Nottingham. The Child \& Co London Lecture 1986, reprinted by kind permission of Professor Smith and Child \& Co.

1. [1984] Statute Law Review 17.

2. Codification of the Criminal Law : A Report to the Law Commission (Law Com. No. 143), 1985. 
accordance with the principles stated in the report. Lord Justice Gibson, who was then Chairman of the Law Commission, has since said ${ }^{3}$ that he now thinks that this was a mistake; we should have been asked simply to state the law as it was. Codification and law reform are different things and should not be confused. So far as this argument relates to major proposals for law reform, like the recommendations of the Butler Committee on Mentally Abnormal Offenders, I acknowledge its force; but, as the Lord Justice recognises, some changes are necessary for "effective and coherent codification." If we had merely restated the law, the product would not have been worthy of the name of Code. The essence of a code is that it should be a consistent and coherent whole. A mere restatement of the present law would necessarily have lacked that essential quality.

I will take as an example the law governing impossibility in the so-called inchoate offences, incitement, conspiracy and attempt. The amount of judicial time devoted to this issue in the higher courts in recent years shows that it is no mere academic problem. A incites $B$ to commit a crime. $B$ agrees to do so, and does all he can to put the agreement into effect. It looks as if $A$ is guilty of incitement, $\mathrm{A}$ and $\mathrm{B}$ of conspiracy, and $\mathrm{B}$ of attempt to commit that crime. But it turns out that, all along, it has been impossible to commit the crime. Where do we find the law which we must now apply? For incitement it is still the discredited rule of the common law stated in Roger Smith. ${ }^{4}$ For the attempt, the matter is regulated by the rule in the Criminal Attempts Act 1981, as now interpreted in Anderton v Ryan..$^{5}$ For conspiracy, the answer depends on whether it is a conspiracy at common law or a statutory conspiracy contrary to s.1 of the Criminal Law Act 1977 - which itself may be a question of some difficulty. If it is a common law conspiracy, the Roger Smith rule still applies; but, if it is a statutory conspiracy, the answer depends on s.1 of the Criminal Law Act 1977, as amended by the Criminal Attempts Act 1981 - which may be the same as the rule governing attempts or may be a third, quite different, rule; no one can say for certain.

We have four categories, regulated by two, or, more likely, three, different rules. No reason has ever been offered as to why different rules should prevail. I do not find that surprising because I believe there is no reason. It is a product of the utterly haphazard growth of the law, both common law and statute. It would not have been beyond the wit of the codification team to restate that irrational jumble; but who, in his right mind, would wish to do that? It is surely inconceivable that it would ever be enacted by Parliament. An essential function of the Code is to introduce consistency and coherence. I believe that the draft achieves it. Clause 54(1) provides:

A person may be guilty of incitement, conspiracy or attempt to commit an offence although the commission of the offence is impossible, if it would be

3. Address to the Annual General Meeting of fustice, 3 July 1985.

4. [1975] A.C. 476.

5. [1985] A.C. 560 overruled on 25 May 1986 by Shivpuri [1986] 2 All E.R. 334 (H.L.). 
possible in the circumstances which he believes or hopes exist or will exist at the relevant time.

We have a single rule applying to the three offences. It occupies four lines. It would replace a mass of confused and confusing case law. I believe that it provides an answer to all the well-known problems of persons inciting, conspiring and attempting to steal from safes or pockets which are in fact empty, to handle goods which they wrongly believe to be stolen, to import parcels which they wrongly believe to contain controlled drugs, to kill people who are already dead, dishonestly to obtain property by statements which they wrongly believe to be false; and so on. The drafting may still be capable of improvement; but I have seen no criticism yet which leads me to doubt whether it will achieve its aim.

Please do not think that this is an isolated example. There are plenty more. Suppose that I have killed your dog and am charged with criminal damage. My defence is that it was attacking me. If I say I was defending my trousers, the Criminal Damage Act 1971 will apply to determine whether my action was justified. But if I say I was defending my leg, the common law is still applicable. And they are different. I will have a better chance of acquittal if I say I was defending my trousers. Trousers, in the criminal law, are more important than legs. Or suppose that, seeing $X$ being attacked by $Y, I$ go to $X$ 's assistance and injure or kill $Y$. If I am charged with an offence against $Y$ and I say I was acting in defence of $\mathrm{X}$, the common law of private defence, with its mass of case-law, determines whether my conduct was justified; but if I say I was acting to prevent a crime being committed by $\mathrm{Y}$, then the matter is governed by section 3 of the Criminal Law Act 1967 which replaced the common law on that subject. As it is very likely that I was acting both in private defence and in the prevention of crime, this is something of a dilemma.

\section{Codification and policy}

The achievement of consistency where it does not exist in the present law necessarily involves some degree of law reform. One of two or more competing rules must be selected or some new rule devised. To deal with impossibility, we selected that rule which we knew that Parliament, after full and well-informed debate, decided should apply to attempts. Parliament's intention was frustrated, partly because of poor draftsmanship, by the decision in Anderton v Ryan. I believe that our clause could not be misunderstood as section 1 of the Criminal Attempts Act was; and I would point out that this was not with the benefit of hindsight. Our report was published before the decision in Anderton v Ryan; but we were conscious of the ambiguity in section 1 , anticipated the risk of misinterpretation and, I believe, removed it.

The choice between competing rules depends on considerations of policy; and we recognise throughout our report that the personal views of three or four academic lawyers on policy are very far from being of overwhelming weight. 
Where policy is embedded in a well-settled rule of law we have generally attempted to restate that rule without regard to whether we might think it right or wrong. But where some public body, principally the Law Commission or the Criminal Law Revision Committee, has found the existing law to be defective and has made recommendations for change, we have attempted to follow as faithfully as possible their proposals. The point that I wish to emphasise today is that if we, or one of these committees, are judged, for any reason, to have made a wrong decision of policy, that in no way impairs the case for codification. Consistency and coherence must then be achieved by substituting the preferred rule for that which we have adopted. In the case of impossibility, any alternative to that which we have proposed would be more complex; it would not go into four lines; and it would be likely to pose more problems of interpretation - all of which seem to me to be good reasons for sticking to the rule proposed; but, if another rule were preferred, it would still be a great advantage to have the single rule in place of the current confusion.

Similarly, I stress - for there is some misunderstanding about this - that the rights and wrongs of the continuing controversy between those whom I may loosely call the subjectivists and the objectivists about the concept of recklessness in the criminal law have nothing to do with the case for codification. Certainly, codification must resolve the controversy; but the merits of codification are the same whether the controversy is resolved in favour of the subjectivists or of the objectivists. Either way, we can achieve consistency and coherence and avoid making irrational distinctions. This is not to say that $I$ think it is not important to make the right choice and I have my own views about that. But, if my views are wrong, then I am in favour of codifying the other, right, view.

In Caldwell ${ }^{6}$ the House of Lords said that the concept of recklessness which has long been held to be implicit in the word "malicious" when used in a statute, involves "fine and impracticable distinctions", and a distinction that "would not be a practicable distinction for use in a jury trial." unaffected by that decision. If the House was right, is it not a public scandal that we are continuing to use (as we have for more than a century) an "impracticable distinction" in serious cases of causing injury to the person, that juries and magistrates are sending people to prison, or letting them go free, on the basis of a distinction which it is not practicable to make? If that is right, the sooner the Caldwell test becomes generally applicable the better.

As the law stands, if a man takes an airgun and, not even considering the possibility that it might be loaded (as is the fact), aims and fires it at $X$, breaking $X$ 's spectacles and destroying his eye, the man will be liable for causing criminal damage to the spectacles but will not be criminally liable at all for the destruction of the eye. ${ }^{8}$ The law gives greater protection to spectacles than to eyes. But,

6. [1982] A.C. 341 .

7. [1982] A.C. at p.352.

8. Wv. Dolbey [1983] Crim. L.R. 681 (D.C.). 
although the man has committed no crime by destroying the eye, if $\mathrm{X}$ dies of the injury within a year and a day, he will be guilty of manslaughter. ${ }^{9}$ No-one ever decided, as a matter of policy, that we should make these strange distinctions - and it is difficult to see how any rational person could decide to make them. It is a historical accident, arising from the haphazard, piecemeal development of the law. What I am pleading for today is not any particular rule but for consistency and coherence, where distinctions, if we make them, are based on reason and not on accident. This can be achieved only by taking an overall view of the whole system, not by tinkering with bits of the law; and that means codification.

\section{Accessibility and comprehensibility}

We claim in our report that codification will make the law more accessible and comprehensible. Some of our critics are very sceptical of that claim. Several of them have been kind enough to say that the principles are now readily accessible and stated in a comprehensible manner in the text book, Smith \& Hogan on Criminal Lam. I would be the last to decry the virtues of that book. But they are far from being the virtues of a code. We try hard to state the law as simply and clearly as possible. But, if the law itself is inconsistent, incoherent and uncertain, the statement of it is inevitably complex and accessible only to the intelligent and determined student. If the Code brings consistency and coherence, it necessarily makes the law more accessible and comprehensible. Were the Code to be enacted tomorrow, the four lines of clause 54(1) would be the sole source of the law on the vexed topic of impossibility. The exposition of it would be infinitely shorter and simpler than is possible today. Or consider the concept of recklessness with its present variety of meanings. My experience of teaching, not only undergraduates, but also members of the profession and, indeed, judges, convinces me that many of them have the greatest difficulty, in grasping these subtleties themselves, and in the case of judges, explaining them to juries. It is not necessary. The concept is capable of definition in short and clear terms. We are criticised for what is seen as our belief that the law can be made simple. I have stated in all five editions of my Law of Theft that that part of the Criminal Law cannot be made, as I put it, "childishly simple". I have not changed my mind about that. In the law of theft, notwithstanding frequent judicial wishful thinking, there is no escape from the complexities of the civil law governing proprietary interests. Of course, there are limits to simplification. But the point is that the present law is very much more complex than it needs to be and it should be made as simple as possible.

\section{Certainty}

Similar scepticism has been expressed about our claim that the Code can make the law more certain. It is objected that the Code would throw up all sorts of new problems of construction, would generate a great mass of new case-law and, in the

9. Cf. Seymour [1983] A.C. 493 (H.L.); Kong Cheuk Kwan v. The Queen [1985] Crim. L.R. 653, 655. 
words of an eminent critic, "the medicine will within a short period of time prove to be worse than the disease." Clearly this must be taken very seriously, because there is no doubt that it could happen. Section 16(1)(a) of the Theft Act 1968, obtaining a pecuniary advantage by deception, the provision which Lord Edmund-Davies dubbed "a judicial nightmare", 10 is a horrible warning of the effects of poor draftsmanship. But that was a provision which was making completely new law, it was prepared in haste while the Theft Bill was going through Parliament, and it did not have the advantage of being considered by the Criminal Law Revision Committee or any similar committee. Another, equally horrific, provision is section 6 of the same Act which is concerned with the meaning of the words "with the intention of permanently depriving the other of [his property]". This section was actually introduced in the name of codification. The CLRC had been content to leave the phrase undefined, to be interpreted in the light of the pre-Theft Act case law. The Home Office, with uncharacteristic enthusiasm, introduced the clause which became section 6 "to make the Bill as complete a statement of the law as practicable, bearing in mind the decision, reached since the CLRC reported, to have a comprehensive Criminal Code." ${ }^{11}$ In the recent case of Lloyd, ${ }^{12}$ the Court of Appeal was inclined to agree with Mr. J. R. Spencer's description of section 6 as a section which "sprouts obscurities at every phrase." 13 The court held that section 6 should be interpreted in such a way as to ensure that nothing is construed as an intention permanently to deprive which would not, prior to the 1968 Act, have been so construed. ${ }^{14}$ Of course, "codification" which has to be construed in that way is not merely useless, it is a great nuisance. If I thought codification had to be, or might be, like that, I would be as firmly opposed to it as anyone. But I am quite convinced it does not have to be like that.

Of course a code will generate case-law. How can it fail to do so when virtually every direction to a jury which results in a conviction is scanned for some defect which might result in the conviction being quashed, including the possible misconstruction by the judge of the relevant legislation? How much case-law it will generate and how damaging its effect will be depends on how well the Code has been drafted and on how well it is interpreted by the courts.

\section{Draftsmanship}

A friendly critic, writing to the Law Commission about the difficulties of draftsmanship, doubts whether I would claim that the codification team could succeed where others have failed. This is no occasion for false modesty; but it is

10. In Royle [1971] 3 All E.R. 1359, 1363.

11. Cited by Mr. J. R. Spencer, "The Metamorphosis of Section 6 of the Theft Act," [1977] Crim.

L.R. 653, 655 .

12. [1985] Q.B. 829 .

13. [1985] Crim. L.R. 653.

14. [1985] 2 All E.R. at p.666. 
for others, not me, to judge how well the drafting has been done. Morever, it is now being subjected to intense scrutiny by many acute minds. If, at the end of this process, we cannot achieve more in terms of clarity than has been attained in criminal statutes in recent years, then we should abandon the enterprise. As I have said elsewhere, I undertook this task with the utmost scepticism whether a group of academic lawyers, with no proven skills in draftsmanship, could do what was required. The comments I have received from some of those with great experience in construing statutes encourages me to believe that I was unduly pessimistic. If so it is not because we are cleverer than (or indeed as clever as) the Parliamentary draftsmen, for whose talents I have the highest respect, but because we are a group who have devoted much of our professional lives to a close study of this particular branch of the law, because we were able to concentrate on the subject for a much longer period than, I suspect, is ever permitted to the Parliamentary counsel and because we worked as a team, each member of which subjected the work of the others to intense, and sometimes humiliating, scrutiny. We may have been inexperienced at drafting, but we were highly experienced at criticising the drafting of others. Above all, we were able and required, to take an overall view and thus avoid inconsistency.

\section{Rules of interpretation}

Our terms of reference required us to consider and make proposals in relation to the rules which should govern the interpretation of the Code. I began by thinking that it was not practicable to formulate rules of construction but I changed my mind and I now think this a vital part of the Code, if we are to avoid the problems which our critics feared. As the Codification Report states, "A prime object of codification is the provision of a clear and authoritative statement of the criminal law." ${ }^{2}$ Even if it succeeds at the outset, it will cease to be that if a meaning is put upon its words which they cannot reasonably bear. The words of the Code then become misleading and a trap. Recent case law shows that there is a danger of this happening in the name of "purposive construction". ${ }^{16}$ If the meaning is plain, I submit that it should be the duty of the court to give effect to that plain meaning, whether it likes it or not. Clause 3(1) is designed to ensure that, as far as possible, (because, inevitably, the courts themselves have the last word) this is done.

But there are bound to be ambiguities. We are criticised for not incorporating the rule that penal statutes must be strictly construed and all ambiguities resolved in favour of the defendant. In my opinion there are powerful reasons for not codifying that rule. We do find it applied from time to time, but, if it had been universally applied, nearly all of the decided cases of statutory construction which have gone in favour of the Crown would have been decided the other way. Strict liability and vicarious liability would be virtually non-existent. As with other rules

15. Para. 3.3.

16. See particularly Ayres [1984] A.C. 447, criticised, [1984] Crim. L.R. 354. 
of construction, the courts apply it when they want to apply it; and, when they do not, they forget about it. But if it were stated in the Code as a rule of universal application it could not be ignored in this way. A much better way forward, in my opinion, is some further search for the true legislative intent. This is often very easily ascertainable, particularly where the legislation is based on a report accompanied by a draft bill as Law Commission reports generally are. If the Report presented to Parliament makes entirely clear what the provision is intended to do, and if the Act faithfully reproduces the terms of the Bill, what justification can there be for resolving an ambiguity by giving it a different meaning? Parliament must surely be presumed to have read and understood the Report presented to it and to have intended the provision to do what the report says it does. Sometimes the court does find its way to the Report, but frequently it does not; and then we have the unhappy spectacle of the court declaring that the statute means " $X$ " because, they say, that is what Parliament must have intended; when the fact is that Parliament intended not " $X$ " but " $Y$ ". Can it really be right that the law should be founded on a demonstrable fallacy? In Donnelly" the Court of Appeal held that under the Forgery and Counterfeiting Act 1981 it is no longer necessary to prove that an alleged forgery "tells a lie about itself" as was required at common law and by the Forgery Act 1913. "There can be no doubt," said the court, "that Parliament intended to make new law." So it did; but not in this respect. More recently in Anderson $^{18}$ Lord Bridge, construing section 1(1) of the Criminal Law Act 1977, said "I do not find it altogether easy to understand why the draftsman of this provision chose to use the phrase "in accordance with their intentions'." $\mathrm{He}$ went on to hold that it means, in effect, "in accordance with the terms of the agreement". But the answer to Lord Bridge's problem was readily ascertainable from the Law Commission Report on Conspiracy and Criminal Law Reform. ${ }^{19}$ The draftsman used the phrase in question because that is precisely what he meant. In both these cases the intention of Parliament was defeated. What is the point of our having expensive Law Commission reports presented to, debated and accepted by Parliament if their intention is to be frustrated by the real or affected ignorance of the courts of what the legislation is intended to achieve? These illustrations by no means stand alone. The Code aims to prevent such misconstruction of its terms, first by the provision of illustrations which it is hoped will show the court clearly what is intended; and second, where the meaning is still ambiguous, by authorising resort to the Law Commission's final report which, it is assumed, will precede the enactment of the Code.

I am persuaded that those provisions, as they now stand, will require some modification; but I am not persuaded that they are unnecessary or undesirable.

17. (1984) 79 Cr. App. R. 76.

18. [1985] 2 All E.R. 961.

19. Law Com. No. 76, 1976, 1.38 and 7.2, recommendation (5). 


\section{The Code and the common law}

The most common and powerful objection to codification is that it would stultify the development of the law, that - as a distinguished critic puts it - it "must inevitably lead to ossification of the law and perpetuation of error."

I accept that there is some force in this argument. In some areas but, I think, very few, codification might preclude development of the law by the courts in ways which would be desirable. Let me give an example. In codifying the common law relating to double jeopardy we had to consider the effect of a conviction in a foreign court. The authority on this is not extensive but it goes back a long way and it is consistent: a conviction in a foreign court is a bar to trial for the same offence in an English court. Clause 15(5) of the draft Code restates that rule. But we had no sooner submitted our report to the Law Commission than the Court of Appeal decided in Thomas $^{20}$ that, although a foreign conviction is usually a bar, this is not so where the accused has been convicted abroad in his absence, has taken no part in the proceedings, is not extraditable and it is very unlikely that the foreign judgment against him could ever be enforced. This perfectly proper development of the common law would, to say the least, have been difficult for the court to make if the draft Code had been in force. The Law Commission will, no doubt, take account of Thomas in any revision they may make of the draft Code; but no legislator however percipient can think of all possible contingencies and, however excellent the ultimate form of the Code, there would certainly arise other unforeseen points where a court might be obliged to say that it must follow the Code with reluctance because it had taken away its power to develop the law. This objection might be of overwhelming weight if there still existed a great body of the common law of crime which was being developed by the courts for the public good. The critics of codification speak as if there were. The Law Commission themselves in their Introduction to the Code quote Sir Leon Radzinowicz:

"The common law of this country, like the forces of growth which determine it, is sui generis; it constitutes an integral part of the national heritage, and discharges a political, social and moral function which is much more precious than the shapely codes which the seekers after a legal paradise aspired to create."

It sounds splendid; but where is this great developing body of law? I look for it in vain. Of the seven thousand or more offences only a handful are not already defined by statute. Murder, manslaughter, affray, assault, perversion of the course of justice, public nuisance and a miscellany of obscure and rarely used misdemeanours are the only survivors. Of course, murder and manslaughter are very important; but is there anything in their development over the last thirty years in which we can take any pride?

20. [1985] Q.B. 604 . 
The Homicide Act 1957 alludes to the mental element of murder as "malice aforethought" (express or implied) - terminology which goes back to the thirteenth century and which does not make sense in modern English. Kenny in 1902 described it as a "mere arbitrary symbol". It is the mental element in murder which distinguishes it from manslaughter and, indeed, from accidental death. It is of crucial importance. Surely, after seven hundred years of common law, there should be no doubt about what it is. Yet today, notwithstanding five decisions of the House of Lords since the Homicide Act, it is impossible to state it with any degree of conviction. Smith ${ }^{21}$ laid down a largely objective test of liability and that led to the passing of Section 8 of the Criminal Justice Act 1967. It then took two decisions of the House, Hyam $^{22}$ and Cunningham ${ }^{23}$ to settle (or so we thought) that it was necessary and sufficient to prove that the defendant knew that it was highly probable that his act would cause death or serious bodily harm, though still leaving in doubt the question whether the act in question must be "aimed at" another. Moloney ${ }^{24}$ decided both that the act need not be aimed at another and that it was not, after all, sufficient that the defendant knew that death or serious bodily harm was highly probable; he must intend one of those consequences; but what is "intention"? The House laid down guidelines for the instruction of juries; but these when used by the trial judge in Hancock and Shankland were promptly held by the Court of Appeal to be defective, ${ }^{25}$ so that the convictions were quashed. The Court of Appeal devised some new guidelines. The House of Lords upholding the decision of the Court of Appeal, has agreed ${ }^{26}$ that the Moloney guidelines are indeed defective and said that it is better not to have any general guidelines at all but does not tell us whether the principles of law enshrined in those formulated by the Court of Appeal are right or wrong. The problem is unsolved and will not go away. The meaning of the word intention is not self evident as is apparent from the widely differing interpretations which have been put upon it by the judges in the last thirty years. Counsel will make submissions about it. If the judge does not offer guidance in his direction, intelligent jurymen will ask questions about it. The judge will have to give a ruling; and I do not envy him his task.

The common law develops slowly; but 700 years to determine the mental element required for our gravest crime is too long. The matter can and should be settled. I venture to claim that if the Code definition of murder and of intention had been in force in 1959, the whole saga from Smith to Hancock and Shankland would have been impossible; and I would submit that that would have been a great gain for the law.

I will not go into the recent history of manslaughter but the story is little if any

21. [1961] A.C. 290.

22. [1975] A.C. 255

23. [1982] A.C. 566 .

24. [1985] A.C. 905.

25. Discussed [1986] Crim., L.R. 181.

26. 27th February 1986. 
better than that of murder. The limits of manslaughter by recklessness, by gross negligence and constructive manslaughter are obscure and confused. ${ }^{27}$ The common law offence of affray has been the subject of judicial development. It was resurrected in Sharp ${ }^{28}$ in 1957 after a long period of desuetude and, as defined in that case, has been steadily expanded in scope - it is no longer a joint offence requiring proof of unlawful fighting by two or more; it no longer need be proved to have taken place in public; if it occurs in a public place it no longer need be proved that anyone other than the victim was present or likely to be present; the victim himself may now be the "bystander" referred to in earlier decisions. ${ }^{29}$ There has been judicial development but surely objectionable judicial development. The judges long ago recognised that it was not for them to create new crimes; but the expansion of old ones is no less objectionable. The recent history of perverting the course of justice is not dissimilar. The common law concept of the disorderly house is so vague that a house may be "disorderly" for reasons ranging from the playing of lawful games for stakes which a jury considers to be excessive to the provision of obscene shows, so the court had little difficulty recently ${ }^{30}$ in holding that provision of certain types of service by a single prostitute could render the house a disorderly one, so by-passing the other rule of the common law that it takes two prostitutes to make a brothel. When the reform of the law of prostitution was being discussed, I observed with interest that some of my judicial friends were very attached to the concept of the disorderly house because it enabled them to put down behaviour which they found - as perhaps we nearly all would - thoroughly reprehensible; but with great respect to them, that is the function of Parliament, not the judges. As for public nuisance, that is such a woolly concept that its potential is scarcely less than that of public mischief which the courts themselves renounced, not only as a crime which may be committed by an individual, but as an object of common law conspiracy.

I have been speaking so far of common law crimes. What about general principles? They are much eroded by statute and survive in pockets with no logical justification. I hope this is adequately demonstrated by the examples which I have given from the law of impossibility and self-defence and the prevention of crime. There is no going back to the pure common law. The only sensible way forward is to consolidate the statutory and common law rules into a consistent principle - i.e. by codifying. Apart from these surviving pockets there are general principles for the construction of criminal statutes like the presumption in favour of mens rea; but these have been applied so haphazardly over the years as to be of very little value. Even the "golden thread" of the presumption of innocence established by the House of Lords in Woolmington has become somewhat tarnished. Codification

27. See commentary on Kong Cheuk Kman v. The Queen [1985] Crim. L.R. at p.788 and authorities cited therein.

28. [1957] 1 Q.B. 552.

29. Attomey-General's Reference (No. 3 of 1983) [1985] Crim. L.R. 207.

30. Tan [1983] Q.B. 1053. 
affords the opportunity to formulate these principles in more precise terms and so to achieve greater predictability in the construction of statutes.

There is, however, one substantial area of common law, namely that governing secondary liability - the law of aiding, abetting, counselling and procuring the commission of offences. Yet in the leading case of the Attorney-General's Reference (No. 1 of 1975$)^{31}$ the Court of Appeal treated the law as if it were already codified (though very imperfectly) by section 8 of the Accessories and Abettors Act 1861 and held that the right approach was to give the four words, "aid, abet, counsel and procure", their ordinary meaning, bearing in mind that each probably has a different meaning "because if there were no such difference, then Parliament would be wasting time in using four words where two or three would do." I happen to believe that this was quite a wrong approach and that it is no more appropriate to seek to give a natural meaning to "aid, abet, counsel or procure" than it would be to try to give such a meaning to "malice aforethought (express or implied)". The court, with scant regard for legal history, proceeded as if these words were used by Parliament for the first time in 1861, ignoring the fact that they had been in use from at least the sixteenth century and had acquired a technical meaning long before 1861, with implications about presence at, or absence from, the scene of the crime and other matters which no-one could possibly discern from the ordinary meaning of the words. When the court had some common law, it failed to recognise it.

With all respect to Sir Leon Radzinowicz and those who take similar views, his rhetoric is without foundation in fact. If we look at the surviving common law of crime we find that it exists only in patches which are the result of historical accidents, that it is frequently uncertain and obscure, if not pernicious and that there is scarcely anything which is worth preserving in its present form.

\section{Objections to judge-made criminal law}

There are, moreover, serious objections to changing the common law of crime by judicial decision, since the change is retrospective. In $\mathrm{Hyam}^{32}$ Lord Hailsham expressed himself relieved at being able to reject the argument of the appellant and to hold that Vickers $^{33}$ had rightly decided in 1957 that an intention to cause grievous bodily harm was still a sufficient mens rea for murder after the Homicide Act 1957 because, he said, if the House had decided to overthrow Vickers "a very high proportion of those now in prison for convictions of murder must necessarily have their convictions set aside and verdicts of manslaughter substituted." But in Moloney ${ }^{34}$ neither Lord Hailsham, nor any other of their Lordships, seems to have had any inhibitions about the similar effect of their decision on Hyam itself. If Moloney is right, it seems necessarily to follow that Mrs. Hyam was herself convicted on a misdirection and that her conviction could have been upheld only

31. [1975] Q.B. 773, at p. 779.

32. [1975] A.C. $55,68$.

33. [1957] 2 Q.B. 664.

34. [1985] A.C. 905,926 . 
by the application of the proviso. Lord Bridge indeed commented that he found it difficult to understand why the prosecution in Hyam did not seek to support the conviction, as an alternative to their main submission, on the ground that there had been no actual miscarriage of justice. The implication seems to be that that would have been the right way to decide the case. But I have some difficulty with Lord Bridge's opinion that no reasonable jury could have failed to convict Mrs. Hyam if they had been told that it must be proved that she intended to cause grievous bodily harm.

How many people are today serving life sentences of imprisonment because, between 1974 and 1985, they were convicted on a Hyam direction which, because of a re-interpretation of the common law is, and always was, wrong? How many have similarly been wrongly convicted of offences under s.18 of the Offences against the Person Act 1861? That is where the change makes the law more lenient. Where it makes it more severe, the effect is that some have been acquitted when, if the law, as we now know it to be, had been properly applied, they might have been convicted. More seriously, the conviction of the first unlucky victims of the expansion of the criminal law infringes the principle of legality - that no one should be convicted for doing an act not previously declared to be an offence.

In one respect the draft Code would preserve judicial creativity. Clause 49 provides that a person does not commit an offence by doing an act which is justified or excused by any rule of the common law, except insofar as the rule is inconsistent with the Code or any other enactment. Nothing in the Code is to limit any power of the courts to determine the existence, extent or application of any such rule of the common law.

The definition of offences in the present law frequently includes the words "without lawful excuse" or "unlawfully". There is no consistency in this usage but, whether these or similar words are used or not, it is clear that recognised general defences - such as duress - apply though no mention is made of them. There is no precisely defined limit to such general defences and, in my opinion, it is not possible to offer a definitive statement of all the principles and rules which may justify or excuse conduct which would otherwise be criminal. Many of these are part of the general law, civil as well as criminal. An example is the law which allows the chastisement of children. If the Code were to provide closed definitions of these rules we might have a situation in which the criminal law forbade conduct which the civil law allowed - which would be absurd - or the civil court might find itself constrained by the terms of the Code in order to avoid a conflict. In including clause 49 we have followed the advice of such eminent authorities as Mr. Justice Stephen and Professor Glanville Williams and the precedents in the Codes of Canada, New Zealand and elsewhere which are based on Stephen's draft. For the reasons I have given, I think such a provision is not only advisable, but essential. An example of its utility is provided, in my opinion, by Mrs. Gillick's case. ${ }^{35}$

35. Gillick v. West Norfolk and Wisbech Area Health Authority [1986] A.C. 112 (H.L.), discussed [1986] Crim. L.R. 113. 
Consider a doctor who provides contraceptive advice for a girl under sixteen, knowing as he may well do, that his advice will facilitate or encourage sexual intercourse between her and a man. The man commits an offence. The House of Lords has told us that the doctor's advice is lawful if the girl has capacity to consent and understands the advice and he believes it to be necessary for the physical, mental and emotional health of the child. If the advice is lawful, the doctor cannot be committing a crime. Yet all the usual conditions for liability as an aider and abettor seem to be satisfied. Generally, it is enough that the defendant knows that his act will assist or encourage the commission of the offence; and it is no answer that he has an unimpeachable motive, or that the offence would be committed anyway or that the encouragement is given through an innocent agent. The House, in my opinion, has propounded a new justification for conduct which would otherwise be criminal. I point this out, not to criticise the result; rather the contrary. It is essential that the courts should be able to consider the social, ethical and public policy issues involved and to reach the conclusion which, in their opinion, these considerations dictated.

I have not, in this lecture, even mentioned the difficulties involved in the enactment of a criminal code. I know these to be enormous. What I have tried to do is to persuade you that it would be worth making considerable effects to overcome them. 